\title{
Dominik Maschek \\ The Meaning of Building Materials in Late Republican Architecture: Moving from Semantics to Pragmatics
}

\begin{abstract}
By exploring the potential of archaeological pragmatics in the analysis of Late Republican architecture, this paper focuses on the ways in which building materials could become charged with meaning. In contrast with traditional approaches which largely deal with the semantics of Roman architecture, its aim is to delineate how the pragmatic power of ongoing construction projects, unfolding across multiple generations, led to the creation of an intricate network of knowledge regarding the choice and usage of specific materials. Ultimately, this leads to the conceptual distinction between two fundamental types of knowledge, expert and vernacular, which had different, albeit equally potent roles to play in the complex social negotiations between Late Republican builders, craftsmen, commissioners, and viewers.
\end{abstract}

Throughout architectural history, building materials have been bearers of meaning. Such a statement, verging upon the banal, might appear uncontroversial, but those who actually want to recover at least snippets of this original meaning are facing a series of obstacles. For example, the meaning of building materials cannot be supposed to have stayed fixed across long periods of time; our modern perception of materials and their qualities will inevitably be compromised by our own social and cultural context; and, last but not least, in antiquity, as indeed at present, the ideas and qualities associated with certain building materials might have oscillated according to different frameworks of reference that were located in the social, political, economic, religious, magical or, more broadly, aesthetic sphere - all of which, to add yet another layer of complexity, was not neatly separable in the first place ${ }^{1}$.

\section{The Case for Archaeological Pragmatics}

In the face of such challenging conditions, most archaeological studies of Roman architecture and its constituent materials have focused on a comparatively narrow definition of meaning, almost exclusively located in either the political or the economic sphere. Without recourse to much theory, it has become widely accepted that the fabric of Roman buildings should best be understood as a 'sign system' which originally addressed an ancient 'viewer' and can thus equally be 'deciphered' by the learned modern interpreter. This approach, relying on the principles of semiotics, is predicated upon the assumption that architecture operates as a semantic system ${ }^{2}$.

Whilst it is not the aim of this paper to dispute such a notion, it is clear that the semantic approach has its limits: most seriously, in its two most popular manifestations it is either based on too few and too simple, or on too many and too complex factors. The former manifests the purely politically and economically focused approach, and it is unlikely that Roman building materials were ever understood merely as conveying an exclusively political or economic message. As for the latter, the conceptual openness of sign systems to an infinite number of possible interpretations,

1 Popkin 2015, 301-303. Amongst a wealth of more recent studies on Roman Republican architecture, design, and materials, see in particular Mattern 1999; 2000; Jackson - Marra 2006; Rous 2009; Bernard 2010; D’Alessio 2010; Nichols 2010; La Rocca 2011; La Rocca - D’Alessio 2011; Jackson - Kosso 2013; Emmerling et al. 2014; Maschek 2014; Mulliez 2014; Demma 2016; Davies 2017; Ducret 2017; Tortorella 2018. The references provided throughout this essay represent only a small fraction of my research on this subject.

2 See Gros 1976; Hölscher 1987; 2004; Zanker 1988, 104-156; 2000; Sauron 1994; Favro 2017.

Ә Open Access. (C) 2022 Dominik Maschek, published by De Gruyter. (cc)BY-NC-ND This work is licensed under the Creative Commons Attribution-NonCommercial-NoDerivatives 4.0 International License.

https://doi.org/10.1515/9783110764734-009 
promulgated most strongly via the various postmodernist 'turns', renders them ineffective for historical analysis of 'more general scope and utility'3. The potentially endless figure of meanings associated with buildings and building materials would only allow for highly personalised accounts of their perception that carry little weight in terms of historical interpretation beyond the purely anecdotal.

One possible way of dealing with this conundrum is to acknowledge that it is virtually impossible to make generalising statements about the way in which Romans collectively understood their built environment and its constituent materials. This acknowledgment then allows us to venture freely into fields like phenomenology and sensory studies. The allure of such approaches notwithstanding, the aim of my paper is to explore a different route, in particular as I do not share the occasional scepticism regarding the attempt to reconstruct broader patterns of meaning behind the use of Roman building materials. That being said, the critics of conventional architectural semantics clearly have a point in stressing its highly reductionist focus on messages and viewers ${ }^{4}$. I thus propose to change the way we look at Roman building materials: from the perception of the sign system to its creation, and thus, from a bewildering semantic openness to the recovery of a comparatively well-circumscribed set of motivations and ideas which formed a subsystem of knowledge quite separate from purely political or economic considerations. The following conceptual sketch therefore works upon the proposition that the meaning of building materials is not best sought 'in the eye of the beholder(s)', but rather in the socially embedded process of architectural creation ${ }^{5}$.

Underpinning this shift from perception to creation is the tripartite concept of archaeological relations - syntactics, semantics, and pragmatics - as defined by David Clarke ${ }^{6}$. Whilst syntactics encompasses a holistic view of the relations between artefacts and all their attributes, semantics only denotes the relations between artefacts and their roles in the physical world, based on the analysis of designata (i. e., the signified, in terms of semiotic theory). Pragmatics, by contrast, refers to the way in which artefacts, their users and observers are related through percepta (performances, buildings, objects and so on) and concepta (norms, values, attitudes and so on). As Clarke succinctly put it: 'The relations that archaeological pragmatics can hope to investigate are those which may suggest association between certain sociocultural organisations and certain sets of attribute or artefact regularities' ${ }^{\text {? }}$ In the following, the pragmatics of Late Republican building materials shall be explored in relation to the material manifestation of the builders' knowledge that was involved in the process of architectural creation.

\section{Late Republican Building Materials: Regaining the Builders' Perspective}

Before we can start discussing the system of meaning within which Republican builders operated when choosing their materials, some general points of methodology seem in order. Traditionally, studies on the architecture and building materials of the Republican period have focused on aspects of chronology, cultural attribution and ideological and political significance ${ }^{8}$. Based on a small

3 Clarke 1978, 38.

4 See Grüner 2014; 2014a; 2017; Haug 2014; Thomas 2014; Popkin 2015.

5 See Busen, this volume.

6 Clarke 1978.

7 Clarke 1978, 483.

8 For the focus on chronology and typology, see e.g., Frank 1924; Blake 1947; Lugli 1957. For the earliest and still one of the most influential attempts at combining dating questions with the assessment of cultural influences in Republican architecture, see Delbrueck 1907; 1912. Cf. Fasolo - Gullini 1953; Boëthius 1978; Gullini 1983; 1992; Coarelli 1987; Osanna - Torelli 2016; Howe 2016. On Late Republican building materials, ideology, and politics, see Pensabene 1998; 
number of select buildings (the round temple by the Tiber in Rome, for example) and seemingly bolstered by a few quotations from Vitruvius and Pliny, the familiar narrative pits an 'Etruscan' or 'Italic' tradition of building against an increasingly 'Hellenised' architecture which emerged in the wake of Roman conquests in the Eastern Mediterranean. In this context, modern scholars often refer to the famous saying, attributed to Cato the Elder, that the primordial 'earthen antefixes of the Roman gods' ${ }^{9}$ were succumbing to the overwhelming power of Greek temple decoration. However, this popular story is problematic in all sorts of ways.

To begin with, the main challenge consists in the fact that, from the completion of the Temple of Capitoline Jupiter in 509 B.C., we have an unbroken series of monumental buildings in Rome and central Italy, but almost no reference whatsoever to the qualities, aesthetic or otherwise, which contemporaries (commissioners, builders, and viewers alike) would have associated with the materials used for their construction. Evidence for an explicit aesthetic discourse on building materials arguably does not start before the first half of the $2^{\text {nd }}$ century B.C., with the plays of Plautus, alongside a few and frustratingly isolated punchlines from the speeches of Cato the Elder that were only reported much later in the accounts of Livy, Gellius, and others ${ }^{10}$. The oft-cited value judgements about the introduction of marble into Roman temple architecture after the destruction of Carthage and Corinth in 146 B.C. probably pertain to the accounts of moralising historians such as L. Calpurnius Piso Frugi, active towards the turn of the century, but they are also only preserved in later works ${ }^{11}$.

A first glimpse of the active involvement of Roman nobiles in matters of architectural practice and design is offered by the suggestive, albeit admittedly rather tenuous, link between the architect Mucius, mentioned by Vitruvius ${ }^{12}$, and the Mucii Scaevolae towards the very end of the $2^{\text {nd }}$ century B.C. ${ }^{13}$. At the same time, eminent statesmen like Q. Caecilius Metellus Macedonicus, Q. Lutatius Catulus, and M. Antonius, the orator, demonstrated an explicit interest in the arts, and their links with prominent contemporary architects such as Hermodorus of Salamis are famously attested ${ }^{14}$. Moreover, the number of architects in inscriptions from Rome and central Italy increases significantly, which equally indicates an enhanced professionalism and concomitant appreciation of architectural design and practice ${ }^{15}$. The same tendency is reflected in the increasingly intense level of experimentation and innovation in the use of opus caementicium in domestic and monumental architecture from the middle of the $2^{\text {nd }}$ century B.C. onwards ${ }^{16}$.

More literary evidence for architectural tastes and fashions comes with Cicero's letters and speeches and, of course, with Vitruvius' treatise at the very beginning of the Principate ${ }^{17}$. However,

Mattern 1999; 2000; Rous 2009; Bernard 2010; Torelli - Marcattili 2010; La Rocca 2011; Marcattili 2011; Steinby 2012; Maschek 2014; McAlpine 2014; Popkin 2015; Tortorella 2018; Yegül - Favro 2019, 127-134.

9 From a consular speech given in 195 B.C.: Liv. 34, 4, 4 f.

10 E. g., Plaut. Mostell. 101-104. 123-128; Liv. 34, 4, 4f.; Gell. NA 2, 20, 6. For full references, see Nichols 2010; cf. Leach 1969; Gruen 1992, 6f. 110-113 (the latter raising fundamental doubts regarding the authenticity of Cato's speech on the lex Oppia as reported by Livy).

11 For example, the description of the Temple of Jupiter Stator, commissioned by Q. Caecilius Metellus Macedonicus, in Plin. HN 36, 24. 34. 40. 42 f. See also Vell. Pat. 1, 11, 3-5, with explicit reference to the luxuria of the temple's building material. On Calpurnius Piso Frugi, see Rawson 1991, 260-267; Cornell 2013, 230-239.

12 Vitr. De arch. 3, 2, 5; 7 Pref. 17.

13 Rawson 1985, 88. 324; Zevi 1996; Anderson 1997, 19. 24-26.

14 Rawson 1975; Gros 1976a; Gruen 1992, 137 f.; von Hesberg 1994, 88. 91-95; Grüner 2004, 28-37; D’Alessio 2010; Leach 2010; La Rocca 2011; Davies 2017, 87-104.

15 Donderer 1996. One particularly interesting case is the nymphaeum at Segni, bearing the (Greek) signature of a certain Quintus Mutius: see Wallace-Hadrill 2008, $125 \mathrm{f}$.; Cifarelli 2020.

16 Jackson - Kosso 2013; D’Ambrosio et al. 2015; Mogetta 2015; 2016; D’Alessio 2016; Marra et al. 2016; Davies 2017, $104 \mathrm{f}$; $2017 \mathrm{a}$

17 Cicero on architecture and building projects, e. g.: Cic. Att. 2, 3, 2. 4, 7; 12, 18. 23. 29. 35-37; 13, 6. 29; 14, 3, 1. 9, 1; Cic. Ad Q. Fr. 2, 2, 1-2; Cic. Fam. 7, 14, 1. 20, 1. See also Anderson 1997, 35-39; 2014, 130 f.; Bernard 2016, 84 f. For Vitruvius, see Knell 1991; Callebat 1994; Romano 1994; Gros 2006; Nichols 2017; Oksanish 2019. 
the bulk of the information upon which we regularly draw to reconstruct the key aesthetic and semantic principles of Roman Republican architecture ultimately derives from Imperial sources, first and foremost Pliny's Naturalis historia. The very nature of these sources poses an insurmountable problem: in the case of Pliny, his references to Republican practice reflect both the sources he was using (mostly Varro, some Vitruvius, Piso Frugi, and Cornelius Nepos) and the aesthetic and moral principles of his own time, i.e., the Late Julio-Claudian and Early Flavian period ${ }^{18}$. We simply cannot assume that value judgements referring to the aesthetics and semantics of building materials remained stable over the course of the centuries; taking Pliny at face value is therefore problematic even when he uses the works of earlier authors from the late $2^{\text {nd }}$ and $1^{\text {st }}$ centuries B.C. in his attempt to collate pertinent information.

By contrast, the 300 years of Republican architecture before Plautus and Cato the Elder are tangible mainly through the archaeologically attested remains. Rather than retrofitting the view of Late Republican and Imperial writers onto these buildings, we should take them seriously as sources for the conscious ways in which architecture was created, revealing frameworks and patterns of meaning that do not (or only barely) feature in our written sources. As soon as we recognise that only a rigorous archaeological analysis will provide the clue to these largely unreported patterns of meaning, the same perspective can fruitfully be taken for buildings of the $2^{\text {nd }}$ and $1^{\text {st }}$ centuries B.C., which, in spite of the presence of some literary texts that refer to architectural thinking and practice, can then be used as a source in their own right.

This also compels us to change the way we look at things. If we acknowledge that the key tenets in semantic studies on Republican architecture, such as the simplistic dichotomies of 'Etruscan/ Italic tradition' versus 'Greek innovation' or 'primordial terracotta' versus 'sophisticated marble', rely on deliberate cultural and literary constructs of the $1^{\text {st }}$ century B.C. and the Early Imperial period, we realise instantly that the notion of monolithic cultural traits is not useful as a framework of analysis. In other words, the use of materials in Republican buildings is not ethnically or culturally conclusive, but rather socially conclusive, with the important subclause that politics is only a subsystem of society. If such use results in specific patterns over time, these patterns must be seen as the outcome of social processes. As a matter of fact, this processual aspect of architectural creation does not unfold in a perfect vacuum: it was always conditioned and guided by networks of knowledge which harkened back to the experience of previous generations of builders.

In this sense, it seems fair to see the process of design and construction in Republican architecture as intrinsically linked with the concept of a 'social memory' that operates as a potent basso continuo underneath short-term political discourse ${ }^{19}$. This social memory spans various generations, i.e., it is not short-lived. However, it is also not as anthropologically rock-solid as Jan Assmann's 'cultural memory', in which, through processes of cultural sedimentation within society, knowledge and norms are deposited over centuries ${ }^{20}$. By contrast, the crucial dynamics in Republican architectural practice can be understood as a perpetuation of knowledge in the medium term, from generation to generation. Seen from the builders' perspective, the recorded patterns of continuity and disruption in the use of building materials over time, freed from political or ethnic interpretations, lead us to a new social chronology of architecture in Republican Rome. This social chronology must form the basis of our exploration if, in a second step, we want to search for meaning ${ }^{21}$.

18 E.g., Plin. HN 36, 1-8. 50 f.

19 Fentress - Wickham 1992.

20 Assmann 1992.

21 A detailed diachronic study on the use of building materials in Republican architecture is currently under preparation by the author. 


\section{From Semantics to Pragmatics: Types and Hierarchies of Knowledge}

Meaning, in the sense of archaeological pragmatics, resides in the fact that materials featured in the decision-making of Roman builders across extended periods of time: they were introduced at a certain moment (innovation) and, if not rejected, went on to be more widely used (acceptance), until they became an integral part of the repertoire (tradition) ${ }^{22}$. Incremental changes and refinements indicate that the framework of knowledge driving this process was not static but constantly evolving, due to permanent re-calibration ${ }^{23}$. Within the overarching framework, I suggest a further differentiation between two different types of knowledge (Fig. 1): expert knowledge (for example, that of a master builder, stonemason or carpenter) and vernacular knowledge (such as, that of an average commissioner who was not an expert in construction ${ }^{24}$ ).

Expert knowledge might manifest itself on two levels. First, on the macro-level of the entire building, for which builders had to consider structural issues when using certain materials. Such considerations usually pertained to an entire set of structurally important components, like the colonnade or podium of a temple. Moreover, knowledge on the macro-level also encompassed the understanding that a particular material was especially prone to damage by water or fire, or resistant to it. In this context, it is important to note that such notions would not necessarily have always been founded upon empirical observation, but could also be derived from magical and religious, or related worldviews. One poignant case in point are the extremely detailed remarks on the impact of the four elements on various sorts of trees and their timber, offered by Vitruvius ${ }^{25}$. This passage seems oddly esoteric to a modern reader, but it is actually based on a precise ontological understanding of nature that is laid out by Vitruvius at the beginning of his chapter on building materials. Citing Thales, Heraclitus, and Pythagoras, he presents an abbreviated theory of the four elements, peppered with the teachings of Democritus' atomistic theory, which he might have imbibed through the highly popular and influential writings of Lucretius ${ }^{26}$. Modern scientific knowledge about particular building materials should thus not simply be taken as an absolute normative framework to which Roman builders would naturally have adhered.

Second, expert knowledge was at work on the micro-level of particular architectural elements, for example when it came to the rendering of decoration, mouldings, roofs etc. In executing these details, stonemasons, carpenters, and other craftsmen followed a code of practice which was transmitted through trans-generational processes of education and might have varied significantly from task to task ${ }^{27}$. Micro-level knowledge therefore introduces a strong undercurrent of tradition which can, at least partly, run counter to the expert knowledge applied on the macro-level: for example, certain stones with strong structural properties might not have been suitable for fine finishing, whilst others which were easy to carve could have been deficient in terms of solidity. Thus, far from being a homogenous set of ideas, the application of expert knowledge on the construction site always oscillated between the macro- and the micro-levels, leading to solutions on what one could

22 This nomenclature was chosen because it reflects the formation of widespread knowledge systems about building materials more neatly than rather mechanistic definitions of technological development such as the 3-phase-model proposed by Greene 2009, 76-80: (1) invention/discovery - (2) innovation - (3) diffusion/technology transfer. In Greene's view, innovation 'is the process by which the invention is brought into use'; by contrast, the sequence of 'innovation - acceptance - tradition' is predicated much more on the socio-cultural formation of normative frameworks and systems of meaning. On the social embeddedness of such processes, see Clarke 1978, $196 \mathrm{f}$.

23 See the important discussion in Bernard 2018, 197-227.

24 For a similar concept with a strong focus on social practice, see the distinction between 'vernacular' and 'academic' building traditions in Deetz 1996, 125-164.

25 Vitr. De arch. 2, 9, 5-17.

26 Vitr. De arch. 2, 2, 1-2. On the influence of Lucretius and Epicuraneism on Vitruvius, see Rawson 1985, 117; Nichols 2017, 8-10. 17. 24.

27 The notion of 'Handwerkstradition' (craft tradition) proposed in Maschek 2012, 26f. 36f. 237-243. 
Fig. 1: Expert and vernacular knowledge in Late Republican architecture.

\section{Expert and Vernacular Knowledge in Late Republican Architecture}

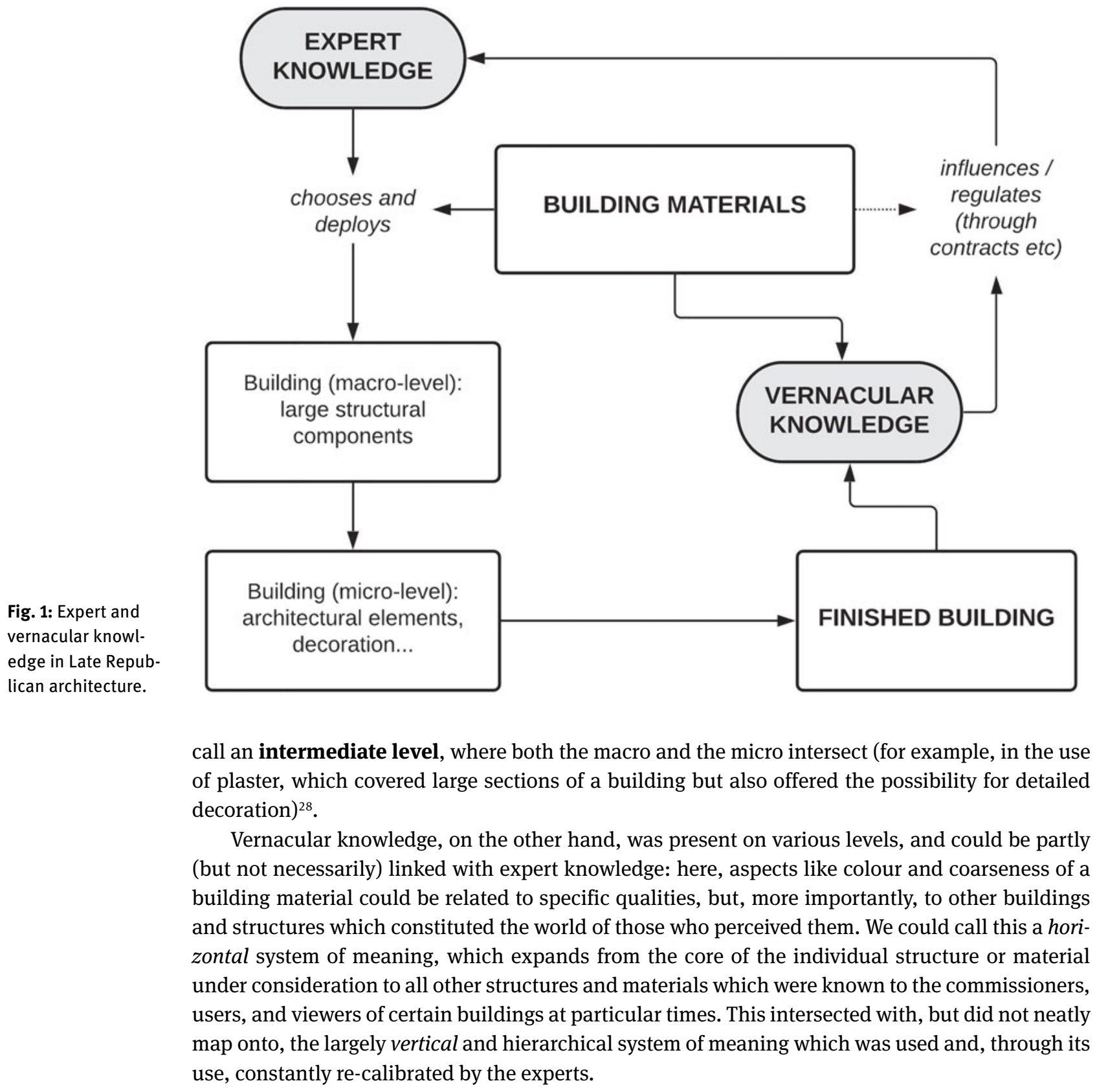

28 See Jackson - Kosso 2013; Bernard 2018, 198 f. 


\section{The Application of Knowledge: Direct and Indirect}

How did these two systems of knowledge condition the process of architectural creation, and thus, the material remains we can still study in the archaeological record? The vertical system of expert knowledge was elaborated in direct relation to the built structure (Fig. 1). Its implementation happened continually during the building process, from the selection of materials through the various stages of their processing to the state of the finished end product. This chaîne opératoire entailed a high degree of experimentation which contributed to a slow and incremental adaptation of expert knowledge over time ${ }^{29}$.

By contrast, vernacular knowledge always stood in an indirect relation to the built structure. The commissioner's aims were formulated in conversation with the builders and formalised via contracts in which the commissioner either asked for specific materials or even put himself under the obligation to provide them ${ }^{30}$. Vernacular knowledge therefore had a constant and powerful (albeit oblique) impact on the process of construction: it was applied by individuals outside the group of expert builders, both before and during the building process, and the demands emanating from it became the legally binding conditions for successful completion of the contract.

Despite these structural differences in how expert knowledge and vernacular knowledge operate, it is important to emphasise that the two intersect at the crucial junction of social control, which was enforced through the framework of contract law. As a consequence, there was always a fundamental asymmetry of power in the extent to which knowledge could shape the built environment: the experts had a clear understanding of materials and how to use them, but the laymen (commissioners) may not have fully shared their views. The result of this crucial intersection - i. e., the expert's knowledge confronted with the commissioner's aspirations - took material shape in the building. The degree to which expert and vernacular knowledge influenced the end product would thus have varied slightly from project to project, but always within the boundaries of current norms and conventions ${ }^{31}$. In spite of the essentially dynamic nature of the process, there are some aspects of the archaeological record that can provide valuable clues about the respective roles of 'expert' and 'vernacular' knowledge on Late Republican construction sites.

For example, it is fairly uncontroversial to ascribe specific techniques of working and manipulating building stones (lifting, dressing, and finishing, for example) to the builders' expert knowledge. However, when it comes to the clearly discernible patterns of stone use over time, things get a bit more complicated, as the introduction of a new material, i.e., innovation, would often have been triggered by the wishes of particular commissioners. The introduction of marble to Roman architecture is a case in point: here we see that the choice of this particular material, starting with the two marble basins at the Arch of Scipio in 190 B.C., was heavily predicated upon the personal preference of particular commissioners ${ }^{32}$. Arguably, the subsequent phase of acceptance, followed by the

29 For the importance of the chaîne opératoire and institutional aspects as conditioning factors in Roman construction projects, see Maschek 2017, 40-42. The fundamental link between social systems, knowledge networks, and production/craftsmanship is explored in Dobres 2000; 2010; Rebay-Salisbury et al. 2014.

30 On institutional frameworks and legal aspects of Roman building contracts, see Martin 1989; Anderson 1997, 68118. For the role of patrons in Roman architecture, see Anderson 2014; Wescoat 2015, 190-197.

31 I would like to emphasise that this position differs significantly from the postmodernist approach recently advocated by Popkin (2015, 301-303), who talks about 'the unstable meanings of individual materials' and postulates that in Roman architecture 'a monument's materiality was not finite and fixed because even if its physical materials remained unchanged, interpretations of those materials shifted constantly'. This idea of constantly shifting interpretations is untenable when confronted with the strikingly patterned structure of the archaeological record. This allows us not only to distinguish between different systems and hierarchies of knowledge and social control, but also to tentatively reconstruct majority views as opposed to eccentric outliers in the use of particular building materials at specific moments in Roman history.

32 On the Arch of Scipio, see Liv. 37, 3, 7. For the use of marble in $2^{\text {nd }}$ century B.C. Roman architecture, see Ducret 2017 with full discussion of literary sources. For the archaeological evidence, see Bernard 2010. 
emergence of a proper tradition in the use of marble, was governed to a much lesser extent by the wishes of individual commissioners, as builders acquired more and more expertise in working with them. It thus seems fair to postulate a decrease of vernacular knowledge in the decision-making process over time, matched by a corresponding increase in expert knowledge. This matches the situation in the $2^{\text {nd }}$ century B.C., with the isolated appearance of powerful commissioners (Q. Caecilius Metellus Macedonicus, D. Iunius Brutus Callaicus) and eminent specialists of foreign extraction (first and foremost Hermodorus of Salamis) in the 140s and 130s B.C., as opposed to the widespread evidence for professional architects working in Rome and Italy from the turn of the century onwards $^{33}$. Of course, these processes of decreasing influence of vernacular knowledge versus the increasing importance of expert knowledge were by no means linear and uniform; moreover, they applied to many different building materials across different timespans, according to the respective historical context (for example, marble from the eastern Mediterranean was introduced at a later moment than 'tufo giallo della via Tiberina', but both were essentially fruits of conquest) ${ }^{34}$. We therefore have to reckon with multiple such processes, to which the archaeological remains bear witness.

From an archaeological point of view, it is important to stress that the structured pattern of occurrence and use of specific building materials in Republican architecture was always strongly tied to the vertical system of expert knowledge. The horizontal system of vernacular knowledge, by contrast, is much harder to pin down. It certainly existed from the very beginning, but in the absence of reliable literary evidence before the turn of the $2^{\text {nd }}$ century B.C., we can only guess its constituent elements, which would have varied according to the social status, education, and interest of the individual commissioner, user or viewer.

\section{Conclusion: The Pragmatics of Late Republican Architecture Between Internalisation and Externalisation}

Ultimately, we can also conceptualise the opposition between expert and vernacular knowledge, essential for the pragmatics of Late Republican architecture, as one of internalisation versus externalisation. Expert knowledge is mostly, if not exclusively, developed and preserved within a particular social group of builders who are organised along the lines of seniority and experience, i.e., according to social generations ${ }^{35}$. This means that the social standing and portfolio of the individual builder decided whether his voice was important and would be heard by his peers. Very often, the tight internal cohesion of this group would have led to the preservation of venerated knowledge, even in the face of rapidly changing customer demand or the arrival of outsiders with different sets of expert knowledge. Existing systems of expert knowledge could be challenged by such outsiders, but more often than not their success or failure was predicated not upon their superior skills, but rather their social position: whether they had important supporters, for instance, or were promoted by influential members of the Roman elite.

By contrast, vernacular knowledge can be described as being mainly influenced by factors external to the building process. The aims of the commissioners and the normative and aesthetic framework of reference for those viewing and using a building and perceiving its materials would not usually have been formed on the construction site. This is the type of context that proponents

33 Rawson 1975; Coarelli 1976; 1983; Gros 1976a; Zevi 1996; D’Alessio 2010; La Rocca 2011; Cavallero 2017; Davies 2017, 80-104.

34 Bernard 2018, 103. 223-226.

35 For the idea of the 'social generation', see Lisón-Tolosana 1983, 170-201; cf. Maschek 2018, 16-18. A similarly useful way of conceptualising social generations is the framework of 'predecessors, contemporaries, consociates, and successors' in Geertz 1973, 364-367. 
of conventional architectural semantics have in mind when they want to reconstruct 'values' and 'ideologies' through the analysis of building materials. But this unduly privileges and thus starkly inflates the importance of vernacular knowledge in the process of architectural creation: never would we expect vernacular knowledge to fully override expert knowledge. Quite to the contrary, it is the intersection between the two that results in the design and erection of buildings, including the choice of their materials.

\section{Dominik Maschek}

University of Oxford

Faculty of Classics

Ioannou Centre for Classical \& Byzantine Studies

66 , St. Giles'

Oxford, OX1 3LU - United Kingdom

dominik.maschek@classics.ox.ac.uk

\section{Illustration Credits}

Fig. 1: D. Maschek.

\section{Bibliography}

Anderson 1997: J. C. Anderson, Roman Architecture and Society (Baltimore 1997)

Anderson 2014: J. C. Anderson, Architect and Patron, in: R. B. Ulrich - C. K. Quenemoen (eds.), A Companion to Roman Architecture (Malden, MA 2014) 127-139

Assmann 1992: J. Assmann, Das kulturelle Gedächtnis. Schrift, Erinnerung und politische Identität in frühen Hochkulturen (Munich 1992)

Bernard 2010: S. G. Bernard, Pentelic Marble in Architecture at Rome and the Republican Marble Trade, JRA 23, 1, 2010, 35-54

Bernard 2016: S. G. Bernard, Workers in the Roman Imperial Building Industry, in: K. Verboven - C. Laes (eds.), Work, Labour, and Professions in the Roman World (Leiden 2016) 62-86

Bernard 2018: S. G. Bernard, Building Mid-Republican Rome. Labor, Architecture, and the Urban Economy (Oxford 2018)

Blake 1947: M. E. Blake, Ancient Roman Construction in Italy from the Prehistoric Period to Augustus. A Chronological Study Based in Part Upon the Material Accumulated by the Late Dr. Esther Boise van Deman, Carnegie Institution of Washington Publication 570 (Washington, DC 1947)

Boëthius 1978: A. Boëthius, Etruscan and Early Roman Architecture (New Haven, CT 1978)

Callebat 1994: L. Callebat, Rhétorique et architecture dans le “De Architectvra” de Vitruve, in: L'École française de Rome (ed.), Le projet de Vitruve. Objet, destinataires et réception du De architectura. Actes du colloque international de Rome, 26-27 mars 1993, CEFR 192 (Rome 1994) 31-46

Cavallero 2017: F. G. Cavallero, Il tempio di Marte in Circo e il suo architetto greco, ASAtene 95, 2017, 317-334

Cifarelli 2020: F. M. Cifarelli, La firma dell'architetto, in: F. M. Cifarelli (ed.), Il ninfeo di Q. Mutius a Segni (Rome 2020) 101-109

Clarke 1978: D. L. Clarke, Analytical Archaeology ${ }^{2}$ (New York 1978)

Coarelli 1976: F. Coarelli, Architettura e arti figurative in Roma, 150-50 a. C., in: P. Zanker (ed.), Hellenismus in Mittelitalien. Kolloquium Göttingen 5.-9. Juni 1974 (Göttingen 1976) 21-32

Coarelli 1983: F. Coarelli, Architettura sacra e architettura privata nella tarda repubblica, in: L’École française de Rome (ed.), Architecture et société. De l’archaïsme grec à la fin de la République. Actes du Colloque international organisé par le Centre national de la recherche scientifique et l'École française de Rome, 2-4 décembre 1980, CEFR 66 (Rome 1983) 191-217

Coarelli 1987: F. Coarelli, I santuari del Lazio in età repubblicana, Studi Nuova Italia Scientifica Archeologia 7 (Rome 1987)

Cornell 2013: T. J. Cornell, The Fragments of the Roman Historians I (Oxford 2013) 
D’Alessio 2010: A. D’Alessio, Fascino greco e 'attualità' romana. La conquista di una nuova architettura, in: E. La Rocca - C. Parisi Presicce (eds.), I giorni di Roma. L'età della conquista. Exhibition Catalogue Musei Capitolini (Milan 2010) 49-64

D’Alessio 2016: A. D’Alessio, Italic Sanctuaries and the Onset of the 'Total Architecture'. Some Observations on the Phenomenon, in: M. Bolder-Boos - D. Maschek (eds.), Orte der Forschung, Orte des Glaubens. Neue Perspektiven für Heiligtümer in Italien von der Archaik bis zur Späten Republik. Akten der internationalen Tagung in Darmstadt am 19. und 20. Juli 2013 (Bonn 2016) 149-163

D’Ambrosio et al. 2015: E. D’Ambrosio - F. Marra - A. Cavallo - M. Gaeta - G. Ventura, Provenance Materials for Vitruvius' harenae fossiciae and pulvis puteolanis. Geochemical Signature and Historical-Archaeological Implications, JASc Reports 2, 2015, 186-203

Davies 2017: P. J. E. Davies, Architecture and Politics in Republican Rome (Cambridge 2017)

Davies 2017a: P. J. E. Davies, A Republican Dilemma. City or State? Or, the Concrete Revolution Revisited, BSR 85, 2017, 71-107

Deetz 1996: J. Deetz, In Small Things Forgotten. An Archaeology of Early American Life 2(New York 1996)

Delbrueck 1907: R. Delbrueck, Hellenistische Bauten in Latium I (Strasbourg 1907)

Delbrueck 1912: R. Delbrueck, Hellenistische Bauten in Latium II (Strasbourg 1912)

Demma 2016: F. Demma, Architetture della 'conquista'. Elementi per la ricostruzione di un dialogo culturale, in: $M$. Aberson - M. C. Biella - M. Di Fazio - P. Sánchez - M. Wullschleger (eds.), L’'talia centrale e la creazione di una koiné culturale? I percorsi della 'romanizzazione’ (Bern 2016) 365-391

Dobres 2000: M.-A. Dobres, Technology and Social Agency. Outlining a Practice Framework for Archaeology (Oxford 2000)

Dobres 2010: M.-A. Dobres, Archaeologies of Technology, Cambridge Journal of Economics 34, 2010, 103-114

Donderer 1996: M. Donderer, Die Architekten der späten römischen Republik und der Kaiserzeit. Epigraphische Zeugnisse, Erlanger Forschungen Reihe A. Geisteswissenschaften 69 (Erlangen 1996)

Ducret 2017: P. Ducret, Réemplois d'éléments architecturaux volés et innovations architecturales. L'introduction du marbre dans la Rome tardo-républicaine, MEFRA 129, 2017, 165-176

Emmerling et al. 2014: E. Emmerling - S. Correll - A. Grüner - R. Kilian (eds.), Firmitas et Splendor. Vitruv und die Techniken des Wanddekors (Munich 2014)

Fasolo - Gullini 1953: F. Fasolo - G. Gullini, Il santuario della Fortuna Primigenia a Palestrina (Rome 1953)

Favro 2017: D. G. Favro, Reading Augustan Rome. Materiality as Rhetoric In Situ, Advances in the History of Rhetoric 20, 2017, 180-195

Fentress - Wickham 1992: J. Fentress - C. Wickham, Social Memory (Oxford 1992)

Frank 1924: T. Frank, Roman Buildings of the Republic. An Attempt to Date Them from Their Materials, Papers and Monographs of the American Academy in Rome 3 (Rome 1924)

Geertz 1973: C. Geertz, The Interpretation of Cultures. Selected Essays (New York 1973)

Greene 2009: K. Greene, Historiography and Theoretical Approaches, in: J. P. Oleson (ed.), The Oxford Handbook of Engineering and Technology in the Classical World (Oxford 2009) 62-92

Gros 1976: P. Gros, Aurea Templa. Recherches sur l'architecture religieuse de Rome à l'époque d'Auguste, BEFAR 231 (Rome 1976)

Gros 1976a: P. Gros, Les premières générations d'architectes hellénistiques à Rome, in: L'École française de Rome (ed.), L'Italie préromaine et la Rome républicaine I. Mélanges offerts à Jacques Heurgon, CEFR 27 (Rome 1976) 387-410

Gros 2006: P. Gros, Vitruve et la tradition des traités d'architecture. Fabrica et ratiocinatio, CEFR 366 (Rome 2006)

Gruen 1992: E. S. Gruen, Culture and National Identity in Republican Rome (Ithaca, NY, 1992)

Grüner 2004: A. Grüner, Venus ordinis. Der Wandel von Malerei und Literatur im Zeitalter der römischen Bürgerkriege (Paderborn 2004)

Grüner 2014: A. Grüner, Licht und Oberfläche bei Vitruv. Überlegungen zum Status sensualistischer Gestaltungsstrategien in der römischen Architektur, in: Emmerling et al. 2014, 415-463

Grüner 2014a: A. Grüner, Vom Sinn zur Sinnlichkeit. Probleme und Perspektiven des Ornamentbegriffs in der antiken Architektur, in: J. Lipps - D. Maschek (eds.), Antike Bauornamentik. Grenzen und Möglichkeiten ihrer Erforschung (Wiesbaden 2014) 25-51

Grüner 2017: A. Grüner, Die Farben des Augustusforums. Der öffentliche Raum als ästhetisches System, in: M. Flecker - S. Krmnicek - J. Lipps - R. Posamentir - T. Schäfer (eds.), Augustus ist tot. Lang lebe der Kaiser! Internationales Kolloquium anlässlich des 2000. Todesjahres des römischen Kaisers vom 20.-22. November 2014 in Tübingen (Rahden 2017) 559-584

Gullini 1983: G. Gullini, Terrazza, edificio, uso dello spazio. Note su architettura e società nel periodo medio e tardo repubblicano, in: L'École française de Rome (ed.), Architecture et société. De l'archaïsme grec à la fin de la République. Actes du Colloque international organisé par le Centre national de la recherche scientifique et l’École française de Rome, 2-4 décembre 1980, CEFR 66 (Rome 1983) 119-189 
Gullini 1992: G. Gullini, Architettura italica ed ellenismo alessandrino, in: N. Bonacasa - A. Di Vita (eds.), Alessandria e il mondo ellenistico-romano. Studi in onore de Achille Adriani (Rome 1992) 527-592

Haug 2014: A. Haug, Das Ornamentale und die Produktion von Atmosphäre. Das Beispiel der Domus Aurea, in: J. Lipps - D. Maschek (eds.), Antike Bauornamentik. Grenzen und Möglichkeiten ihrer Erforschung (Wiesbaden 2014) 219-239

von Hesberg 1994: H. von Hesberg, Formen privater Repräsentation in der Baukunst des 2. und 1. Jahrhunderts v. Chr. (Cologne 1994)

Hölscher 1987: T. Hölscher, Römische Bildsprache als semantisches System, Abhandlungen der Heidelberger Akademie der Wissenschaften, Philosophisch-Historische Klasse 1987, 2 (Heidelberg 1987)

Hölscher 2004: T. Hölscher, The Language of Roman Images (Cambridge 2004)

Howe 2016: T. N. Howe, Hellenistic Architecture in Italy. Consuetudo Italica, in: M. M. Miles (ed.), A Companion to Greek Architecture (Chichester 2016) 470-486

Jackson - Kosso 2013: M. D. Jackson - C. K. Kosso, Scientia in Republican Era Stone and Concrete Masonry, in: J. DeRose Evans (ed.), A Companion to the Archaeology of the Roman Republic (Chichester 2013) 268-284

Jackson - Marra 2006: M. D. Jackson - F. Marra, Roman Stone Masonry. Volcanic Foundations of the Ancient City, AJA 110, 2006, 403-436

Knell 1991: H. Knell, Vitruvs Architekturtheorie. Versuch einer Interpretation ${ }^{2}$ (Darmstadt 1991)

La Rocca 2011: E. La Rocca, La forza della tradizione. L'architettura sacra a Roma tra II e I secolo a.C., in: La Rocca D’Alessio 2011, 1-24

La Rocca - D'Alessio 2011: E. La Rocca - A. D'Alessio (eds.), Tradizione e innovazione. L'elaborazione del linguaggio ellenistico nell'architettura romana e italica di età tardo-repubblicana (Rome 2011)

Leach 1969: E. W. Leach, De Exemplo meo Ipse Aedificatio. An Organizing Idea in the Mostellaria, Hermes 97, 1969, 318-332

Leach 2010: E. W. Leach, Fortune's Extremities. Q. Lutatius Catulus and Largo Argentina Temple B. A Roman Consular and his Monument, MemAmAc 55, 2010, 111-134

Lisón-Tolosana 1983: C. Lisón-Tolosana, Belmonte de los Caballeros. Anthropology and History in an Aragonese Community ${ }^{2}$ (Princeton, NJ 1983)

Lugli 1957: G. Lugli, La tecnica edilizia romana. Con particolare riguardo a Roma e Lazio II (Rome 1957)

Marcattili 2011: F. Marcattili, Primo stile e cultura della luxuria, in: G. F. La Torre - M. Torelli (eds.), Pittura ellenistica in Italia e in Sicilia. Linguaggi e tradizioni. Atti del Convegno di Studi, Messina 24-25 settembre 2009 (Rome 2011) 415-424

Marra et al. 2016: F. Marra - E. D’Ambrosio - M. Gaeta - M. Mattei, Petrochemical Identification and Insights on Chronological Employment of the Volcanic Aggregates Used in Ancient Roman Mortars, Archaeometry 58, 2016, 177-200

Martin 1989: S. D. Martin, The Roman Jurists and the Organization of Private Building in the Late Republic and Early Empire, Latomus 204 (Brussels 1989)

Maschek 2012: D. Maschek, Rationes decoris. Aufkommen und Verbreitung dorischer Friese in der mittelitalischen Architektur des 2. und 1. Jhs.v. Chr., Wiener Forschungen zur Archäologie 14 (Vienna 2012)

Maschek 2014: D. Maschek, Der Tempel neue Kleider? Rezeptionsästhetische und semantische Aspekte von Bauornamentik im spätrepublikanischen Mittelitalien, in: J. Lipps - D. Maschek (eds.), Antike Bauornamentik. Grenzen und Möglichkeiten ihrer Erforschung (Wiesbaden 2014) 181-202

Maschek 2017: D. Maschek, Transfer, Rezeption, Adaption. Archäologische Erklärungsmodelle zur Verbreitung römischer Steinarchitektur zwischen Struktur und Prozess, in: J. Lipps (ed.), Transfer und Transformation römischer Architektur in den Nordwestprovinzen. Kolloquium vom 6.-7. November 2015 in Tübingen (Rahden 2017) 35-45

Maschek 2018: D. Maschek, Die römischen Bürgerkriege. Archäologie und Geschichte einer Krisenzeit (Darmstadt 2018)

Mattern 1999: T. Mattern, 'Vielheit und Einheit'. Zu Erscheinungsbild und Wirkung römischer Tempelarchitektur, BJb $199,1999,1-30$

Mattern 2000: T. Mattern, Der Magna-Mater-Tempel und die augusteische Architektur in Rom, RM 107, 2000, 141-153

McAlpine 2014: L. J. McAlpine, Marble, Memory, and Meaning in the Four Pompeian Styles of Wall Painting (Ph.D. diss. University of Michigan 2014)

Mogetta 2015: M. Mogetta, A New Date for Concrete in Rome, JRS 105, 2015, 1-40

Mogetta 2016: M. Mogetta, The Early Development of Concrete in Domestic Architecture of Pre-Roman Pompeii, JRA 29, 2015, 43-72

Mulliez 2014: M. Mulliez, Le luxe de l'imitation. Les trompe-l'œil de la fin de la République romaine, mémoire des artisans de la couleur, Collection du Centre Jean Bérard 44 (Naples 2014)

Nichols 2010: M. F. Nichols, Contemporary Perspectives on Luxury Building in Second-Century B. C. Rome, BSR 78, 2010, 39-61 
Nichols 2017: M. F. Nichols, Author and Audience in Vitruvius' De architectura (Cambridge 2017)

Oksanish 2019: J. Oksanish, Vitruvian Man. Rome under Construction (Oxford 2019)

Osanna - Torelli 2016: M. Osanna - M. Torelli (eds.), Sicilia ellenistica, consuetudo italica. Alle origini dell'architettura ellenistica d’Occidente. Atti del convegno, Spoleto, Complesso monumentale di S. Nicolò 5-7 novembre 2004 (Pisa 2016)

Pensabene 1998: P. Pensabene, Il fenomeno del marmo nella Roma tardo-repubblicana e imperiale, in: P. Pensabene (ed.), Marmi antichi II. Cave e tecnica di lavorazione, provenienze e distribuzione (Rome 1998) 333-390

Popkin 2015: M. L. Popkin, Decorum and the Meanings of Materials in Triumphal Architecture of Republican Rome, Journal of the Society of Architectural Historians 74, 2015, 289-311

Rawson 1975: E. Rawson, Architecture and Sculpture. The Activities of the Cossutii, BSR 43, 1975, 36-47

Rawson 1985: E. Rawson, Intellectual Life in the Late Roman Republic (London 1985)

Rawson 1991: E. Rawson, Roman Culture and Society. Collected Papers (Oxford 1991)

Rebay-Salisbury et al. 2014: K. Rebay-Salisbury - A. Brysbaert - L. Foxhall (eds.), Knowledge Networks and Craft Traditions in the Ancient World. Material Crossovers (New York 2014)

Romano 1994: E. Romano, Dal De officiis a Vitruvio, da Vitruvio a Orazio. Il dibattito sul lusso edilizio, in: L’École Française de Rome (ed.), Le projet de Vitruve. Objet, destinataires et réception du De architectura. Actes du colloque international de Rome, 26-27 mars 1993, CEFR 192 (Rome 1994) 63-93

Rous 2009: B. Rous, An Age without Images. Architectural Decoration in the Late Republican Period, in: P. Lulof - C. Rescigno (eds.), Deliciae Fictiles IV. Architectural Terracottas in Ancient Italy. Images of Gods, Monsters and Heroes. Proceedings of the International Conference Held in Rome (Museo Nazionale Etrusco di Villa Giulia, Royal Netherlands Institute) and Syracuse (Museo Archeologico Regionale 'Paolo Orsi') October 21 $1^{\text {st }}-25^{\text {th }} 2009$ (Oxford 2009) 84-94

Sauron 1994: G. Sauron, Quis Deum? L'expression plastique des idéologies politiques et religieuses à Rome à la fin de la République et au début du Principat, BEFAR 285 (Rome 1994)

Steinby 2012: E. M. Steinby, Edilizia pubblica e potere politico nella Roma repubblicana (Milan 1994)

Thomas 2014: E. Thomas, On the Sublime in Architecture, in: J. Elsner - M. Meyer (eds.), Art and Rhetoric in Roman Culture (Cambridge 2014) 37-88

Torelli - Marcattili 2010: M. Torelli - F. Marcattili, La decorazione parietale domestica romano-italica tra fase medio-repubblicana e cultura della luxuria, BA online 1, 2010, 40-54

Tortorella 2018: S. Tortorella, Terrecotte architettoniche, stucchi, pitture. Affinità reciproche tra generi diversi di arte decorativa, $\mathrm{ArchCl} 69,2018,197-221$

Wallace-Hadrill 2008: A. Wallace-Hadrill, Rome's Cultural Revolution (Cambridge 2008)

Wescoat 2015: B. D. Wescoat, The Patronage of Greek and Roman Architecture, in: C. Marconi (ed.), The Oxford Handbook of Greek and Roman Art and Architecture (Oxford 2015) 176-202

Yegül - Favro 2019: F. K. Yegül - D. G. Favro, Roman Architecture and Urbanism. From the Origins to Late Antiquity (Cambridge 2019)

Zanker 1988: P. Zanker, The Power of Images in the Age of Augustus (Ann Arbor, MI 1988)

Zanker 2000: P. Zanker, Bild-Räume und Betrachter im kaiserzeitlichen Rom, in: A. H. Borbein - T. Hölscher - P. Zanker (eds.), Klassische Archäologie. Eine Einführung (Berlin 2000) 205-226

Zevi 1996: F. Zevi, Le élites municipali. Mario e l’architettura del tempo, Cahiers du Centre Gustave Glotz 7, 1996, 229-252 